\title{
Dialogens arrangement: \\ Når muslimer og kristne mødes
}

\author{
Lise Paulsen Galal
}

\begin{abstract}
Abstrakt
Denne artikel satter fokus på religionsdialogen som et arrangeret kulturm $\phi d e$, der har til formål at skabe fredelig

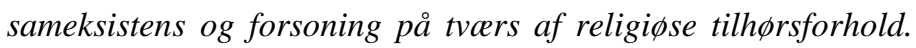
Med afsat $i$ en teologisk forståelse af dialog undersøges, hvad arrangementet betyder for den transformation af deltagerne, som religionsdialogen anticiperer. På baggrund af interviews med dialogarrang $\phi$ rer og observationer af dialogarrangementer analyseres det spandingsfelt af forskelle, som arrangementet har til formål at overskride. Der sattes sarligt fokus på betydningen af arrangementets rituelle karakter og de forskelssatninger af subjektet, som indrammer dialogen.
\end{abstract}

I slutningen af juli 2015 kunne man følge en diskussion i Kristeligt Dagblad, hvor en række debattører udtrykte kritik af Københavns biskop, Peter Skov-Jakobsens rolle som initiativtager til et nyt tværreligiøst forum med titlen jødisk-kristent-muslimsk forum i København. Initiativet var en reaktion på skudangrebene på Krudttønden og synagogen i København i februar 2015 foretaget af en tilsyneladende radikaliseret, ung, muslimsk mand. Etableringen af forummet foregik i et samarbejde mellem religiøse ledere fra de tre religioner med blandt andet det formål at bekæmpe religiøst betinget hate crime og at sikre religionsfriheden, herunder mindretallenes (Skov-Jakobsen 2015). Sognepræst Marie Høgh kritiserede blandt andet biskoppen for at blande religion og politik (Enevoldsen 2015). Initiativet er et eksempel på et af mange, hvor dialog anses som redskab til konfliktløsning og fredelig sameksistens. Baggrunden og kritikken afslører samtidig, at motiver, personer og politisk kontekst er væsentlige aspekter af dialogens udformning og responsen på samme.

Det er ikke usædvanligt, at dialoginitiativer motiveres af konkrete hændelser. Et andet eksempel er 'Det arabiske initiativ', som den danske regering introducerede i 2003. Hvis dette ikke var direkte motiveret af terroranslaget mod USA den 11. september 2001, så var denne og senere andre konflikter, såsom Mohammed-tegninge-krisen i 2005-06, med til at legitimere initiativets fortsatte eksistens. Med 'Det arabiske initiativ' ønskede regeringen at styrke demokratiseringsprocesser i Mellemøsten og Nordafrika, men også at 
styrke dialogen med den arabiske verden. ${ }^{1}$ Et 'Dansk-Egyptisk Dialoginstitut' blev etableret i Egypten, og forskellige aktører (ngo'er, uddannelsesinstitutioner $\mathrm{m} . \mathrm{fl}$.) igangsatte diverse dialoginitiativer $\mathrm{i}$ regionen med støtte fra initiativet. Så sent som i oktober 2015 offentliggjorde Udenrigsministeriet en evaluering, der viste, at netop dialogen og samarbejdet var en helt central del af programmets succes (Ministry of Foreign Affairs of Denmark 2015). Men hvad har dialogen mellem muslimer, kristne og jøder i Danmark at gøre med dialog som redskab i understøttelsen af demokratiseringsprocesser i Mellemøsten? Og hvad er det, der gør dialogen til et fejret instrument til konfliktløsning?

Svarene på disse spørgsmål kan ligesom dialogens væsen studeres fra flere perspektiver, som for eksempel filosofiske, teologiske, politiske og sociologiske (se f.eks. Hansen 2015; Rasmussen 1997; Riis 2006). I denne artikel vil jeg i modsætning til mange af disse studier ikke forsøge at definere, hvad dialog er, eller hvad den $b \phi r$ føre til, men se på dialogen som et arrangement med egne karakteristika, der finder sted i konkrete samfundsmæssige og politiske sammenhænge. Denne tilgang er inspireret af de spørgsmål, vi stiller i forskningsprojektet 'The Organised Cultural Encounter', som er et kollektivt forskningsprojekt, der udforsker forskellige typer af 'arrangerede kulturmøder'. ${ }^{2}$ Projektet unders $\emptyset$ ger arrangerede kulturmøder som en social praksis, herunder hvordan organiseringen af kulturmøder finder sted, hvad der sker i mødet, og hvad dette producerer.

Arrangørerne fremstiller ofte dialogen som et nærmest neutralt og universelt redskab til konfliktløsning, der ikke kun handler om at ændre eller transformere relationen mellem deltagerne, men også om løsning af makropolitiske konflikter. Der synes at være en forventning om, at ændringer på et mikroniveau baseret på 'nære' og 'personlige' møder kan føre til ændringer på et makroniveau. Spørgsmålet er, hvordan bagvedliggende motiver og politisk virkelighed er med til at strukturere dialogens udformning, gennemførelse og resultat. At besvare dette spørgsmål kræver, at man undersøger dialogen i dens konkrete situeringer.

Netop religionsmødet er, med hændelser som de ovennævnte, blevet fremstillet som særligt vanskeligt. Som Titus Hjelm skriver, så har den politiske opmærksomhed over for religionen nået nye højder de seneste ca. 20 år. "Fear of 'parallel societies', religiously inspired terrorism, human rights violation, and loss of national identity in the face of mass immigration" har alt sammen ført til stigende bevidsthed om religionen som kilde til sociale problemer (Hjelm 2014: 213). Mens den politiske udmelding i en europæisk kontekst er, at religiøst

\footnotetext{
${ }^{1} \mathrm{Se}$ http://detarabiskeinitiativ.dk/om/ (læst 1. december 2015).

2 Projektet er finansieret af Det Frie Forskningsråd med bevillings-ID: DFF1319-00093. Se også projektets hjemmeside: https://organisedculturalencounter.wordpress.com/
} 
tilhørsforhold kun kan tolereres, så længe det underordnes loyalitet over for nationalstaten (Wolf 2012: 37), så synes religionsdialogen at tage et andet afsæt.

I denne artikel er fokus på det interreligiøse dialogmøde og herunder særligt mødet mellem muslimer og kristne. Med udgangspunkt i erfaringer fra deltagelse i dialogarrangementer mellem danskere og egyptere, kristne og muslimer i Danmark og Egypten, og fra interviews med arrangører og iagttagere af dialogmøder i og mellem Danmark og Mellemøsten, vil jeg argumentere for det frugtbare $i$ at studere religionsdialogen som en særlig form for social praksis. I den forbindelse sætter jeg særligt fokus på, hvordan arrangementet har karakter af et overgangsritual, der gennem forhandlinger af forskelssætninger har som mål at etablere rammer for en mulig transformation af deltagerne. Med andre ord kigger jeg på organiseringen bag og kategoriseringerne under dialogmødet, samt på hvordan udefra kommende 'forstyrrelser' bliver produktive. ${ }^{3}$ Først vil jeg give et kort indblik i baggrunden for religionsdialogen i Danmark.

\section{Hvem arrangerer?}

Organisatorer af religionsdialog i Danmark er hovedsageligt kristne organisationer og institutioner som for eksempel missionsselskaber og kirker, samt ngo'er, der arbejder med spørgsmål relateret til indvandring. Som missionsselskab på et folkekirkeligt grundlag har Danmission således mange års erfaring med dialogarbejde både $\mathrm{i}$ forbindelse med indvandring til Danmark og i udviklingsarbejdet. ${ }^{4} \mathrm{Et}$ andet eksempel er stiftssamarbejdet 'Folkekirken og Religionsmøde', der blev etableret i 2002 med det formål at styrke folkekirkens engagement $i$ det flerreligiøse samfund, herunder at fremme dialogen. ${ }^{5}$ Et sidste eksempel, jeg vil nævne, er Islamisk-Kristent Studiecenter, som blev etableret af muslimer og kristne i fællesskab i 1996, og som udover Danmission har været en stærk drivkraft i arbejdet med at fremme religionsdialogen i en dansk kontekst. Også muslimske organisationer og foreninger arrangerer dialogarbejde. En institutionaliseret version heraf er Dialogforum, der blev etableret $\mathrm{i}$ 2002 af unge nydanskere med tyrkisk baggrund, og som har tætte bånd til Gülen-bevægelsen. ${ }^{6}$ Også jødiske organisationer og institutioner har været aktive, som nævnt i indledningen.

De ovenstående initiativer tager direkte afsæt i forskelle mellem religioner og ønsket om at bygge bro over religiøse

\footnotetext{
${ }^{3}$ Stor tak til Kirsten Hvenegård-Lassen, RUC, for læsning, kommentarer og forslag til ændringer.

${ }^{4} \mathrm{Se}$ http://danmission.dk/hvad-gor/dialog/ (læst 15. oktober 2015).

${ }^{5} \mathrm{Se}$ http://www.religionsmoede.dk/index.php/om/folkekirke-ogreligionsmode (læst 4. november 2015).

${ }^{6} \mathrm{Se} \mathrm{http://dialogin.dk/pages/profil/om-foreningen} \mathrm{(læst} \mathrm{8.} \mathrm{august} \mathrm{2015).}$
} 
modsætningsforhold, samtidig med at de ser religionen som en del af løsningen. Derudover findes en række andre dialoginitiativer i Danmark, hvor religion indgår som en kategori blandt mange andre, men ikke som en særlig privilegeret position. Eksempler er 'Dansk Ungdoms Fællesråds Dialogambassadører'7 og 'Grænseforeningens Kulturmødeambassadører'. ${ }^{8}$ Der er glidende overgange mellem de forskellige modeller for arrangerede kulturmøder. På tværs af initiativerne finder man ønsket om at nedbryde fordomme om etniske, nationale, religiøse og nogle gange også kønnede forskelle. Et andet fællestræk er ideen om, at dialogen gennem organiseringen heraf er anvendelig for nedbrydning af sådanne fordomme. Ved at styre dialogen, i sammenligning med hverdagens samtaler, gøres forandring mulig. Til det formål findes også manualer eller håndbøger, der vejleder læseren $\mathrm{i}$ at anvende dialogen som redskab. ${ }^{9}$

I det følgende er det arrangementer, som eksplicit ønsker at bygge bro over religiøse modsætningsforhold, der belyses. Danmissions arbejde med dialog er et illustrativt eksempel den forbindelse. I udviklingsprojekter i blandt andet Mellemøsten indgår religionen som betydningsfuld faktor, idet forskelle, fjendskab og konflikt mellem mennesker med forskellige religioner ses som en barriere for det samarbejde, der er nødvendigt for at skabe udvikling og/eller forandring. Blandt andet med støtte fra det arabiske initiativ og i partnerskab med lokale organisationer, har Danmission derfor det seneste årti stået bag en række dialoginitiativer i blandt andet Libanon, Jordan og Egypten. Initiativerne svinger mellem at have karakter af konference, hvor vidensformidling står i centrum, til at have karakter af workshop, hvor deltagerne "sætter sig selv på spil". I det sidste tilfælde lægges der vægt på, at dialogen er erfaringsbaseret, som også Henrik Lindberg Hansen identificerer som en af flere dialogtyper (Hansen 2009). De enkelte arrangementer er sjældent rent det ene eller andet, men har elementer af begge dele. ${ }^{10}$ Deltagerne kan være religiøse ledere og/eller professionelle og frivillige i ngo'er, eller civilsamfundsaktivister engageret $i$ at styrke lokale forhold og udvikling. Hvor indsatserne er skrevet ind $i$ forskellige udviklingsperspektiver, er det kendetegnende, at der samtidig blandt aktører som Danmission er en forestilling om en spill-over effekt fra indsatsen i Mellemøsten til indsatsen i Danmark. Således forventes danske deltagere i dialogarrangementer, der foregår i Mellemøsten, til en vis grad at vende hjem med erfaringer, der kan komme den hjemlige dialog til nytte.

\footnotetext{
${ }^{7} \mathrm{Se} \mathrm{http://duf.dk/dufs-arbejde/dufs-dialogambassadoerer/} \mathrm{(læst} \mathrm{5.} \mathrm{december}$ 2015).

${ }^{8} \mathrm{Se}$ http://www.ambassador.graenseforeningen.dk/ (læst 5. december 2015).

${ }^{9}$ Både Dansk Ungdoms Fællesråd, Danmission og Folkekirke og

Religionsmøde har udarbejdet sådanne guidelines.

${ }^{10}$ Ifølge interview med dialogkonsulent ved Danmission, Agnete Holm.
} 


\section{Religionsdialog mellem teologi og social praksis}

På trods af utallige studier af muslimers møde med det såkaldte sekulære kristne Europa (jf. Kivisto 2014) og ikke mindst af de problemer, det fører med sig af manglende integration, intolerance og terrorisme, har religionsdialogen ikke fået nogen særlig opmærksomhed i studierne af, hvordan man for eksempel sikrer bedre og mere ligeværdig medborgerskab. En undtagelse i den forbindelse er dog antologien 'Vendepunkter', der blandt er optaget af det religiøse sprogs betydning for konflikt og forsoning (Sjørup 2007). I den interkulturelle kommunikationsforskning betragtes religion primært som en identitetskategori blandt andre, der kan føre til gensidige misforståelser baseret på forudforståelser og fordomme (se f.eks. Tranekjær 2007). Hvorimod religionsdialogen som sådan til gengæld sjældent har været genstand for interkulturel kommunikationsanalyse (Wolf 2012: 38). Alain Wolfs forsøg på en sådan indskriver sig til gengæld i rækken af forsøg på at indkredse en ideel model for 'sand' dialog, som han dernæst måler forskellige politikker for religionsdialog op imod. På denne baggrund peger han på nødvendigheden af at tage religionen eller snarere troen alvorligt, hvis man vil dialogen (ibid.: 46).

Netop dette afsæt $i$ at tage religionen alvorligt er måske baggrunden for, at religionsdialogen - som genstandsfelt for forskning i en dansk sammenhæng - i høj grad er blevet overladt til dens udøvere. Det vil sige, at mens udøverne typisk er kristne aktører, er det primært teologer, der har forsøgt at forstå og begrunde religionsdialogen. I Danmark har teologer som blandt andre Theodor Jørgensen, Hans Raun Iversen og Lissi Rasmussen skabt teologisk grundlag for en tværreligiøs dialogpraksis, som de til dels også selv har været aktivt involveret i. Således er Lissi Rasmussen en af initiativtagerne, bestyrelsesformand og daglig leder af Islamisk-

Kristent Studiecenter, ligesom Hans Raun Iversen er bestyrelsesmedlem samme steds.

Overordnet set kan religionsdialogen inden for en folkekirkelig og dansk teologisk kontekst ses som en videreudvikling af og erstatning for missionsbegrebet. I en erkendelse af, at tvang, trusler og lokkemidler i kombination med kolonialisme og imperialisme ofte har været virkemidler til at få ikke-kristne til at konvertere, er missionsbegrebet i den folkekirkelige sammenhæng blevet omdefineret til at handle om dialog. Denne udvikling har sin parallel i udviklingen af en global teologi, som ifølge Wolf er inspireret af begrebet 'dialogisme' (Wolf 2012). Denne forsøger på forskellige måder at adressere behovet for at kunne samtale med andre, om deres opfattelser af sandheden, selv om den er i modstrid med ens egen. Særlig fremtrædende i den forbindelse er den tyske teolog og filosof, Paul Tillich, som gennem analysen af mødet mellem buddhisme og kristendom opstiller retningslinjer for en meningsfuld dialog, der 
blandt andet involverer begge parters evne til at repræsentere sin egen religiøse tro (ibid.: 40). Et fortsat relevant element fra traditionel mission er derfor vidnesbyrdet, som argumenteres mulig at forene med dialogen (Jørgensen 2000).

Tre aspekter synes at være særligt centrale for religionsdialogen. Det første er netop vidnesbyrdet, eller ideen om at "den kristne tro er et godt udgangspunkt i mødet med dem, som bygger deres liv på andre traditioner" (Vejledning i religionsmøde 2008). Det er gennem en tydelig formulering "af egen tro" og åbenhed "om egne motiver", at samtale under trygge former for begge parter bliver mulig (ibid.). Det andet aspekt er spørgsmålet om, hvad der adskiller henholdsvis forener menneskene, hvor religionsdialogen synes at stræbe efter, at deltagerne får oplevelsen af at være menneske sammen, eller med Grundtvigs ord "Menneske først - kristen saa". Theodor Jørgensen formulerer det således: "Det bærende i religionsdialog må være et engagement, som man erkender og anerkender at være fælles om. Det er kort fortalt at være menneske og helst et godt og sandt menneske." (Jørgensen 2000). Der er samtidig en opmærksomhed på, at det universelt menneskelige potentielt udfordres af det partikulære, eller forskelssætningerne, og at man dermed løber en risiko ved at indgå i dialogen (ibid., Vejledning i religionsmøde 2008). Det tredje aspekt er, at mфdet eller relationen i sig selv har en transformativ karakter. Dét at være sammen og anerkende hinandens tilstedeværelse synes lige så vigtig som troens ord. Investeringen i dialog og nærhed $\mathrm{i}$ relation til religionsdialog trækker samtidig på en arv fra grundtvigsk inspirerede ideer om oplysningen som et dialogisk (i øjenhøjde), folkeligt (i kontrast til elitært) og integrerende projekt. Her trækkes desuden på en protestantisk (Luthersk og Grundtvigsk) forståelse af kristendommen som placeret i hverdagslivet. En tilgang, der er yderligere accentueret $\mathrm{i}$ forståelsen af diapraksis som en udvikling af religionsdialogen, hvor det er igennem fælles handlen, at man begynder at forstå og anerkende hinanden som ligeværdige mennesker på tværs af religion (Jørgensen 2000; Rasmussen 1997).

Der er hos forfatterne og i manualerne en opmærksomhed på, at religionsdialogen er vanskelig, risikofyldt og potentiel konfliktfyldt. Vejledning i religionsmøde (2008) taler om villigheden til "at udsætte sig for åbenhedens risiko". Derfor kræves netop et faciliteret eller arrangeret møde, der følger specifikke retningslinjer for dialog, som deltagerne bør tilegne sig. Der synes at være konsensus om, at efterfølgelsen af sådanne retningslinjer åbner mulighed for at håndtere eller endda overskride de spændinger, der udspringer af den sociale virkelighed og dennes indlejrede magtrelationer. Det sker ved at møde 'den Anden' som menneske frem for repræsentant for en kategori, for eksempel 'muslimen'. Ambitionen om at opstille idealmodeller for dialog har betydet, at der kun i begrænset omfang er forsket i, hvad der konkret sker i et møde, der er arrangeret i overensstemmelsen med religionsdialogens specifikke retningslinjer. Vil man nærme sig dette, 
kan man for eksempel spørge, hvordan nye subjektpositioner forhandles, overskrides og skabes i religionsdialogen.

For at besvare dette spørgsmål er der grund til kort at opholde sig ved forståelsen af kultur, som noget folk gør, og ikke som en determinant, der eksisterer isoleret fra praksis (Abu-Lughod 1991; Ortner 2006). Det medfører, at kultur er noget, der skabes i praksis, og derfor må analyseres i dens empiriske sammenhæng og som et resultat af historisk situerede institutioner og subjektiviteter etableret gennem disciplinerende praksisser (Foucault 2002). Religionsdialogen bliver som et arrangeret kulturmøde således produktivt i dets bestræbelse på at skabe gensidig forståelse. Det er gennem udforskningen af denne produktivitet, at vi derfor får en større forståelse af i dette tilfælde religionsdialogen som social og disciplinerende praksis. 'Et arrangeret kulturmøde' er i denne sammenhæng defineret som et møde mellem mennesker (professionelle, såvel som ikke-professionelle), der er bragt sammen i kraft af deres tilskrevne kulturelle forskellighed med det formål at etablere relationer, samarbejde og/eller fredelig sameksistens på tværs af forskellene.

De tilskrevne forskelssætninger er derfor en forudsætning for det arrangerede religionsmøde. Forskelssætningerne er resultatet af en subjektiveringsproces, hvor aktører handler på - act upon - samtidig med at de påvirkes af - enacted or determined by - eksisterende kulturelle betingelser (Foucault 2003, 2002; Hall 1996; Staunæs 2003). Processer af subjektivering er dermed altid influeret af kollektive kategoriseringer, som muliggør og begrænser specifikke handlinger. Hvad angår arrangerede kulturmøder, er sådanne kategoriseringer eksplicitte med normativt prioriterede positioner. Det vil sige, at mens enhver subjektivering kan opfattes som kulturel ontologisk set, så er det den eksplicitte kulturelle subjektivering, der udstikker rammerne for det arrangerede kulturmøde, og dermed den eksplicitte religiøse subjektivering, der definerer rammerne for religionsdialogen.

Mens der eksisterer spredte studier af, hvad der kan defineres som arrangerede kulturmøder (jf. Askin and Pain 2011; Müller 2012), så har religionsdialogen hidtil kun i begrænset omfang været analyseret med et sådan perspektiv. Denne artikel tager det første skridt $\mathrm{i}$ analysen af religionsdialogen som et arrangeret kulturmøde. Baseret på interviews med dialogarrangører og facilitatorer samt casestudier af arrangerede dialogmøder ${ }^{11}$, diskuterer jeg, hvordan religionsdialogen $\mathrm{i}$ sit arrangement forsøger at håndtere det spændingsfelt, hvori deltagernes erfaringer med at blive 'acted upon'

\footnotetext{
${ }^{11}$ Det empiriske grundlag for diskussionen er seks interviews med danske arrangører af religionsdialog, skriftlige materialer om religionsdialog udarbejdet af arrangører, samt egen deltagelse i 3 religionsdialogarrangementer med deltagere fra Danmark og Egypten. Disse var arrangeret $\mathrm{i}$ et samarbejde mellem Danmission, Islamisk-Kristent Studiecenter og den egyptisk NGO, CEOSS (Coptic Evangelical Organisation of Social Service).
} 
og 'acting' forstyrres. Hvad jeg i det følgende belyser, er ikke en udtømmende analyse af den arrangerede religionsdialog. Hertil kræves flere case-baserede feltstudier. Det er i stedet et fors $\emptyset \mathrm{g}$ på at slå ned på udvalgte elementer af arrangementet, der inviterer til analytisk opmærksomhed. Denne analytiske opmærksomhed kan med fordel anvendes i kommende case-analyser. ${ }^{12}$

\section{At sætte scenen: et 'safe space'}

Allerede inden religionsdialogen er begyndt, er den kendetegnet ved at placere deltageren i et spændingsfelt mellem frygt og utryghed på den ene side og forventning om positiv forandring på den anden. Foranlediget af Danmissions egne spørgsmål til en kommende deltager, udfylder han dette spændingsfelt med følgende svar på spørgsmålet om, hvad han tror, bliver en udfordring:

Mangel på forståelse og miskommunikation. Der skal være plads til at udtrykke sine holdninger uden at skulle føle sig forulempet, derfor er det vigtigt, at man har et "safe space", hvor der er plads til forskellige holdninger og meninger. ${ }^{13}$

Den positive forventning udtrykker han således:

Jeg ser frem til at høre de andre deltageres historie. Jeg håber, at jeg denne uge selv bliver udfordret på mine egne synspunkter, rykker mine egne grænser og lærer noget nyt hver dag. ${ }^{14}$

Allerede inden afgang er den kommende erfaring med religionsdialog dermed indskrevet i erfaringens 'messiness', hvor retningen af forandringen er uforudsigelig. Som Sara Ahmed skriver i en artikel om ideen om lykke: "My starting point is the messiness of the experiential, the unfolding of bodies into worlds and what I think of as 'the drama of contingency', how we are touched by what comes near." (Ahmed 2007: 124).

Arrangørernes svar på dette uforudsigelige rod er forsøget på at skabe rammer - et safe space, hvor indenfor rodet kan håndteres. Det er en villet - med Masseys begreb - 'throwntogetherness' (Massey 2005: 151). Det er chancen for at møde en uventet nabo, der medfører en uundgåelig uforudsigelighed, som netop derfor kræver regulerende

\footnotetext{
${ }^{12}$ Se endvidere fortkommende artikel (2016) af Kirsten Hvenegård-Lassen og Lise Paulsen Galal med titlen "Transformative spaces between chaos and order: On the analysis of organised cultural encounters" (foreslået til Ethnicities).

${ }^{13} \mathrm{Se}$ http://danmission.dk/blog/2015/09/02/hvorfor-vil-du-til-libanon-ogoeve-dialog/ (læst 2. november 2015).

${ }^{14} \mathrm{Se}$ http://danmission.dk/blog/2015/09/02/hvorfor-vil-du-til-libanon-ogoeve-dialog/ (læst 2. november 2015).
} 
sociale institutioner (ibid.). Det er i den forbindelse, at arrangørerne træder til i etableringen af et særligt dialogrum, som ifølge dem kræver tid at opbygge. Som en af arrangørerne forklarer:

Det kræver jo de første 2-3 dage at få skabt det der rum. Det som jeg - vi kalder et safe space, hvor folk langsomt kan udtrykke sig ud fra sig selv.

Det vil sige, at frygt og transformation, rum og tid er helt centrale aspekter af religionsdialogen, som skal håndteres af både arrangører og deltagere. Med Sara Ahmeds perspektiv kan denne konstellation anskues som subjekter såvel som kroppe, der frygter (føler) og skal transformeres (acted upon and acting) i tid og rum. Det er et rum, hvor spændingerne og ubehaget set fra arrangørernes side er produktivt (Askins og Pain 2011). Eller som Derrida udtrykker det: "Chaos is at once a risk and a chance" (Derrida i Massey 2005: 151). I religionsdialogen er det således i spændingerne mellem forsøget på at skabe orden og forstyrrelserne udefra, at noget produceres.

På den måde har religionsdialogmødet mindelser om overgangsritualet, hvor man hives ud af sin normale sociale position, for $i$ et afgrænset tidsrum, en liminal fase, at skulle igennem en række prøvelser sammen med andre. Den liminale fase er kendetegnet ved kaotiske tilstande, som for at blive produktiv kræver streng rituel kontrol. Mens man træder ind til den liminale fase med én social position, ophæves denne under tilstedeværelsen i den liminale fase, hvorefter man træder transformeret ud igen og kan optage en ny social position i den samme kontekst, som man i sin tid forlod (jf. Gennep 1960).

For at transformation kan ske, skal der altså både være kaos, samtidig med at dette kaos skal styres. Her er det, at arrangørerne for alvor kommer ind i billedet. En måde at skabe denne form for organiseret kaos, er at rykke deltagerne ud af deres hverdagsliv, for at lade dem mødes et nyt og 'fremmed' sted og med nye og 'fremmede' mennesker. Derfor lader man for eksempel en gruppe danskere, der selv repræsenterer forskellighed og dermed indbyrdes fremmedhed, rejse til Egypten for at møde en ligeså sammensat gruppe. Det kan være et sted i Mellemøsten eller i Danmark, eller det kan, når det handler om interne danske møder være $\mathrm{i}$ en kirke eller et mødested indrettet til formålet. For at styre denne potentielt ukontrollable situation guider og faciliterer arrangørerne dialogen. De førnævnte manualer kan ses som en drejebog for en sådan facilitering, der afspejler ideer om dialogmødets formål, udfordringer og deltagernes rolle i relation til en $\varnothing$ nsket forandring.

Som i overgangsritualet kan andre ritualer anvendes til at facilitere forandringen. I religionsdialogen kan dette være fælles bøn eller pilgrimsfærd, som jeg senere vil give et eksempel på. Den fælles bøn på tværs af religion er ikke ualmindelig og nævnes fx også af 
Københavns biskop i forbindelse med jødisk-kristent-muslimsk forum. Også disse bør dog foregå under styrede former, som det fremgår af Vejledning i Religionsmøde (2008), afhængig af omstændigheder og format. Når det er nødvendigt med en omhyggelig forberedelse, skyldes det ifølge vejledningen hensyntagen til den enkeltes religiøse integritet.

\section{At tildele roller: forskelssætningens paradoks}

Hvis arrangementet skal lykkes, forventes deltagerne i et vist omfang at overgive sig til drejebogen. Allerede $i$ forberedelsen af arrangementet tildeles de specifikke kropsligt indlejrede subjektiveringer, idet de inviteres på baggrund af tilskrivning af religiøs, etnisk og national identitet.

I forbindelse med de studerede dialogarrangementer mellem grupper af danskere og egyptere, som alle enten mødtes i Danmark eller Egypten, blev deltagerne således sammensat, så der både var muslimer og kristne i begge grupper. På trods af forsøget på at finde danske deltagere med både etnisk anden og dansk baggrund inden for begge religiøse grupperinger, endte 'muslim' oftest med at være lig med 'anden etnisk baggrund' og 'kristen' lig med 'etnisk dansk baggrund'. I modsætning hertil syntes den egyptiske gruppe alle at blive positioneret som etniske egyptere. Allerede $\mathrm{i}$ disse subjektpositioneringer trådte den politiske virkelighed ind og satte rammerne for de tilskrevne roller, som deltagerne forventedes at tage på sig. Dette blev yderligere understreget, da en af arrangørerne under et dialogarrangement i Minya, Egypten, tilskrev kategorierne særlige kulturelle kendetegn.

Dialogarrangementet bestod af en blanding af både akademiske og erfaringsbaserede fremlæggelser af modeller for dialogarbejde på den ene side, og på den anden side sessioner, hvor deltagerne blev delt i grupper for at diskutere og for at træne dialog. Inden det første gruppearbejde blev ideen med dette præsenteret af en af de danske medarrangører, der udover at give os ideer om, hvad vi skulle starte med at tale om, også indledte med følgende karakteristik af deltagerne. Hun påpegede, at de respektive deltagere fra de to lande ikke skulle undre sig, hvis deltagerne opførte sig forskelligt i dialoggrupperne. Danskerne var ifølge hendes fremstilling nemlig vant til eller foretrak at snakke sammen først og dernæst danse, mens egypterne var parate til at danse først og dernæst snakke sammen. Ideen bag hendes analogi var, så vidt jeg forstod, at danskerne godt kan være reserverede og have behov for at lære hinanden nærmere at kende, inden de kaster sig ud i en åbenhjertig debat, mens det modsatte altså skulle gøre sig gældende for egypterne. Det betød også ifølge den danske arrangør, at egypterne skulle give plads til danskerne for at tale, for ellers ville de ikke tage ordet. 
Karakteristikken vandt muligvis en vis genklang hos danskerne, men da vi kom ud i grupperne, brugte den gruppe, jeg deltog i, en del tid på at forklare de egyptiske deltagere, hvad hun havde ment. De kunne ikke umiddelbart genkende sig selv i karakteristikken og havde $\mathrm{i}$ det hele taget ikke fanget pointen med 'at danse'. Det var karakteristisk for den gruppe, jeg var i, at flertallet af egypterne talte længere og mere engageret end flertallet af danskerne. Havde arrangøren så ret? To af de fire danskere i gruppen argumenterede åbent for deres manglende engagement med, at de havde deltaget $\mathrm{i}$ mange af denne slags dialogarrangementer, hvoraf dette var en i rækken. De havde derfor ikke så meget at sige om det spørgsmål, vi var blevet bedt om at diskutere, nemlig hvad vi gerne ville opnå, inden mødet var slut.

I forbindelse med et andet arrangement i samme møderække, som foregik i Danmark, havde jeg følgende oplevelse:

Jeg sidder på en af de bagerste rækker i en blandet gruppe af egyptere og danskere. En yngre kvinde og muslim fortæller om muslimer i Danmark. Ved siden af mig sidder en kvinde på omkring de 50, der på et tidspunkt på engelsk hvisker mig i øret: hvorfor taler de så meget om religion?

De nævnte eksempler illustrerer, hvordan drejebogens kategorier ikke altid resonerer med deltagernes forventninger. For det første giver de tilbudte subjektpositioner ikke altid mening for deltagerne, som eksemplet med de dansende egyptere illustrerer. For det andet træder andre subjektpositioner ind og forstyrrer drejebogen. Det gælder når de tilsyneladende professionaliserede danske dialogdeltagere har mistet engagementet, som får dem til snarere at træde ind i subjektpositionen som 'professionelle' repræsentanter for en kategori, end som nysgerrigt søgende 'fremmede' over for andre 'fremmede'. Noget der om noget syntes at svække muligheden for gennemførelsen af den erfaringsbaserede dialog. For det tredje afslører den egyptiske kvindes skepsis over fokusset på religion, hvordan der ikke altid er overensstemmelse mellem organisatorernes drejebog og deltagernes.

På trods af en anerkendelse af relevansen af at bringe kristne og muslimer sammen blandt både egyptere og danskere, afspejlede kvindens skepsis en udbredt holdning blandt egypterne. For dem var dagsordenen ikke at forstå 'den Anden', men at sikre rammer for sameksistens med 'den Anden' gennem civile og sociale rettigheder. Mens udfordringen blandt ikke mindst de unge muslimske deltagere i den danske gruppe på dette tidspunkt (i 2004) var at finde og definere sin egen position som muslim i det danske samfund for dernæst at diskutere rettigheder og anerkendelse.

Eksemplerne illustrerer, at dialogen ikke kan afkobles fra den kontekst og de personer, der deltager. For det første kan dialogen ikke isoleres til kun at handle om religion, og deltagerne kan ikke isoleres 
til at optræde alene på baggrund af én tilskrevet subjektposition. For det andet er konteksten for, hvad deltagerne vender tilbage til, styrende for hvad der sker under dialogen. Spørgsmålet er, hvad arrangementets karakter og drejebogen kommer til at betyde for, hvad sådanne udefrakommende forstyrrelser kommer til at producere. Med overgangsritualet i mente kan man stille spørgsmålet om, hvilken ny position deltagerne forventes at træde ud $\mathrm{i}$, når de forlader den liminale fase, og om denne er tilstrækkelig kontekstfølsom. Jeg vil i det følgende give tre eksempler, der viser, at religionsdialogen aldrig kun handler om religion eller tro, og at religionsdialogen kan have forskellige måder at tackle forstyrrelserne på.

\section{Eksempel 1: Når erfaringen forstyrrer}

Ligesom i ritualet forventes deltagerne at transformeres gennem dialogens udspændthed mellem kaos og orden. Således bliver frygten for at blive præsenteret for en anden sandhed en frygt, som det er facilitatorens rolle at transformere til noget produktivt. Et eksempel herpå var reaktionerne på en libanesisk kvindes tilslutning til brugen af vold.

Og jeg kan huske et år. Jeg havde nogle deltagere, nogle shiamuslimer nede fra det sydlige Libanon, helt nede ved grænsen til Israel. Og en af pigerne oplevede, at hendes far blev dræbt for øjnene af hende af en israelsk soldat under krigen mellem Hisbollah og Israel [...] Så hun havde jo en masse følelser, erfaring og smerte i sit forsvar for brug af voldelig modstand. Meget forståeligt. $\mathrm{Og}$ så sidder der nogle danskere, som jo selvfølgelig sidder og ikke er for voldelig modstand og bla bla bla. Og det, og pludselig blev folk så vrede, at flere muslimer trak "nå men de er jo også korsfarende", og jeg ved ikke, hvad der ikke blev trukket op, og 9/11, og pludselig så eskalerede det, ikk'. Så handler det om "puhh.. okay, nu sætter vi os ned" [...] Der fik jeg snakket med dem om, at det handler om, at vi lige hører på hende, ikk'. Og hun fik tid til at fortælle, og alle kunne forstå hende. Og så blev der også lyttet til og forstået den ikkevoldelige modstand. [...] Og da hun forstod, at hun var blevet hørt, da kunne hun høre den anden side. Og det samme med... Der skete der så noget magisk, at de pludselig opdagede "nå men det er jo ikke meningen, at vi skal være enige".

Da jeg videre spurgte, hvordan det var magisk, var svaret:

At der er en forløsning i rummet. Et sådan haaaaaa.. Det er ligesom om en spænding bliver forløst til... fra at være en ubehagelig spænding til at være en velkommen spænding, der 
godt må være der og godt kan rummes. Og en forløsning, som for nogen erfares som en forsoning. En forsoning, der ikke hedder "nu er vi blevet ens og enige", men en forsoning der hedder "nu kan vi godt rumme og forstå, at vi tænker forskelligt".

Under sin fortælling refererede facilitatoren til, hvordan hun blandt andet måtte forklare deltagerne dialogens 'spilleregler' for at få løst den opståede konflikt. De konkrete konflikter forventedes suspenderet i kraft af en gensidig accept af hinandens positioner. Facilitatoren forsøgte at at sige at skabe et trygt rum, hvor konkrete konflikter kunne italesættes og anerkendes som individuelle erfaringer. Denne suspendering blev yderligere understøttet af en kort pilgrimsvandring. Facilitatoren fortalte videre:

Og så senere hen på sådan en uge, nogen gange gør jeg det, at jeg sætter folk sammen to og to, en kristen og muslim. Når jeg har lært dem lidt at kende, så kan jeg parre dem. Så sender jeg dem på en pilgrimsvandring sammen, og siger lidt om pilgrimsvandringerne $\mathrm{i}$ islam og kristendom. Og så går de afsted, og så dem der ikke rigtig ved, hvad de skal bruge deres tid til, dem giver jeg nogle spørgsmål, de kan tage med. Men det, de skal dele, er deres troshistorier, altså deres personlige troshistorier. Anfægtelser, tvivl og vrede på Gud, men også perioder hvor det har givet trøst, og alt sådan noget. Og så er der jo nogen, der siger, at de ikke er troende. Det er fint, de har stadig en form for ideologihistorie $\mathrm{i}$ det mindste eller en værdihistorie igennem deres liv. Ja, så det handler ikke om, at den ene skal derop og vise den anden, det handler simpelthen om at bygge relationer. [...] Og når det så kommer tilbage efter nogle timers vandring, fordi det her tager nogle timer, så er de fuldstændigt... mange af dem er fuldstændigt benovede og har aldrig oplevet noget lignende, fordi de så finder ud af, at den anden har noget, der er lige så smukt, som det de selv har, noget de kan genkende. [...] Og pludselig får man en indgang til den andens religion, som ikke handler om en indgang, der hedder via dogmatikken eller via den ene store religion over for den anden, men en indgang til den andens religion fra noget mere personligt og noget mere smukt. $\mathrm{Og}$ så får man interesse for den andens religion eller tro personligt gennem et andet menneske. Og så kan man bedre rumme den anden.

Det lykkedes tilsyneladende for facilitatoren hos deltagere at skabe lydhørhed over for den individuelle erfaring og derigennem opnå større forståelse for en anden holdning end ens egen. Denne forståelse for en anden erfaringsposition styrkedes yderligere gennem pilgrimsturen, hvor den individuelle og personlige troshistorie bliver 
udgangspunktet for dialog. Der bragtes orden i det kaos, som den libanesiske kvindes opbakning til voldelig modstand medførte, ved at træne deltagerne til at se 'den Anden' som et menneske. Man kan sige, at forskelssætningerne på denne måde delvis opløstes og erstattedes af menneske-til-menneske-relationer. Det er samtidig værd at bemærke, at facilitatoren anvendte begreber som magi, forløsning og pilgrimsfærd i sin forklaring af, hvad der skete. Dette rituelle og religiøse vokabular eller register kan ses som et supplement til et andet register med fokus på refleksionen. Det rituelle register fremstår som et redskab til at skabe orden i kaos og etablere et safe space.

Tilbage står, at den position, der står parat til at gribe en, når man træder transformeret ud af dette safe space, synes at være positionen som menneske. Spørgsmålet er, om denne position bydes velkommen i den kontekst, man træder ud i, som i mellemtiden ikke har forandret sig, men hvor konflikten lever videre på en anden skala.

\section{Eksempel 2: Når storpolitik forstyrrer}

Det allerede omtalte dialogmøde i Minya fandt sted i efteråret 2006, hvor kulminationen på Mohammed-tegninge-krisen trekvart år tidligere blev et uomgængeligt tema for dialogen. Mødet blev indledt med et oplæg af en dansk akademiker, der havde karakter af vidensformidling. Det var en kritisk, men også autoritativ analyse af, hvordan Mohammed-tegninge-krisen kunne forklares, set fra et dansk perspektiv. Oplægget kritiserede blandt andet Jyllandspostens dispositioner set i lyset af en generel anti-muslimsk diskurs i det danske samfund, og på den måde positionerede taleren sig som værende kritisk over for tegningerne. Det var en positionering, der tydeligt vandt genklang i gruppen af danske deltagere.

Alligevel fortsatte emnet med at poppe op i efterfølgende sessioner, hvorimod det ikke dukkede op i gruppearbejdet (hvor jeg deltog), hvor dialogøvelser var i centrum. Tilsyneladende blev gruppen af danskere mere og mere trætte af at skulle tale som tegninge-krisen. I forbindelse med et oplæg, hvor et af de aktive medlemmer af Islamisk-Kristent Studiecenter i København fortalte om centrets arbejde med diapraksis, blev han efterfølgende spurgt af en ung muslimsk, egyptisk kvinde om, hvordan centret havde reageret på tegninge-krisen. Herunder hvad de havde gjort for at bygge bro mellem muslimer og kristne. Dette forekom at være et yderst relevant spørgsmål på et dialogmøde, der netop havde fokus på forskellige dialogmodeller. Mens oplægsholderen forsøgte at svare, kom den akademiker, der havde holdt det indledende oplæg, op og hviskede til ordstyreren (som i dette tilfælde var mig), at denne skulle stoppe diskussionen og forhindre, at tegninge-krisen blev ved med at dukke op som emne. 
Det var bemærkelsesværdigt, at den mest dominerende religionskonflikt i nyere tid i Danmark blev opfattet som et illegitimt emne. Det forstyrrede tilsyneladende på en forkert måde og blev i modsætning til den libanesiske kvindes fortælling i mit første eksempel ikke genstand for en påmindelse om at lytte til hinanden, men blev i stedet forsøgt gjort tavs. En opfattelse af, at man havde bekendt kulør, kombineret med en vis udmattelse blandt de danske deltagere, hvad angik emnet, kan naturligvis forklare reaktionen. En anden forklaring kan knyttes til sammenligningen med den libanesiske kvindes fortælling. Denne blev gjort tilgængelig gennem den personlige erfaring, mens tegningekrisen af danskerne synes at blive indskrevet i kollektive kategorier af danskhed, ytringsfrihedsfundamentalister, halalhippier, islamofober etc. Tegningekrisen var siden krisens kulmination $\mathrm{i}$ den danske kontekst blevet et omdrejningspunkt for italesættelsen af en række kollektive identiteter. Spørgsmålene fra de egyptiske deltagere i Minya kunne derfor opleves som endnu en et fors $\emptyset \mathrm{g}$ på at kategorisere danskere kollektivt som enten islamofober eller naive multikulturalister. Når samtidig disse kollektive kategorier ikke var i overensstemmelse med deltagernes selvopfattelse, gav det dem problemer i forhold til at navigere mellem karikerede subjektpositioner og en subjektposition som dansk kristen eller muslim med helt andre personlige erfaringer med religionsmødet. Tegningekrisen blev, som mens den stod på, en grænsemarkør, som det aldrig lykkedes arrangørerne at hjælpe deltagerne til at overskride. Tværtimod styrkede den grænsesætningen mellem 'os' (danskerne) og 'dem' (egypterne) og cementerede oplevelsen af Muhammed-tegningekrisen som et udtryk for en uløselig kulturel og religiøs konflikt mellem Mellemøsten og Danmark.

Eksemplet illustrerer, at religionsdialogen ikke altid lykkes med at skalere samfundsmæssige konflikter ned på det individuelle og interpersonelle niveau. Det synes særligt vanskeligt, når deltagerne indskrives i kollektive forskelssætninger, der er bundet op på specifikke kontekster, som ikke nødvendigvis forstås på samme måde af i dette tilfælde henholdsvis de egyptiske og danske deltagere. I dette tilfælde lykkedes det ikke at opløse forskelssætningen, som faciliteret af dialogen burde have sikret. Det efterlader igen en usikkerhed om, hvad deltagerne træder ud til, når de forlader mødet. Den ny position, der burde stå til deres rådighed efter mødets transformation af deltageren, bliver uklar, når man træeder ud i en kontekst, der ellers forties.

\section{Eksempel 3: Når den lokale kontekst forstyrrer}

En aften efter middagen under dialog-mødet i Minya sad en mindre gruppe danskere og egyptere sammen. Den ene egypter, en præst, 
fortalte den ene vittighed efter den anden, hvoraf mange med en vis ironi berørte det ulige forhold mellem kristne og muslimer i Egypten og gjorde grin med de religiøse eller politiske autoriteter.

Den egyptiske stor-mufti, den koptiske pave Shenouda og en jødiske religiøs leder dør og kommer sammen i himlen. På grund af deres fremtrædende position giver ærkeenglen Gabriel dem hver især ret til et sidste $\varnothing n s k e$. Den jødiske leder starter med at sige: "jeg ønsker alle muslimer døde", hvorefter den muslimske stor-mufti siger: "jeg ønsker alle jøder døde". Shenouda har stået tavs, og Gabriel henvender sig til ham og spørger om hans $\emptyset$ nske. Shenouda afviser ydmygt: "nej nej, jeg har skam intet ønske". Men Gabriel insisterer på, at det var en aftale, at alle tre havde ret til et $\varnothing$ nske. Igen afviser Shenouda bestemt og siger: "jeg ønsker slet ingenting. Jeg vil være helt tilfreds med, at de to andre får deres ønsker opfyldt.” (Galal 2007: 37)

Vittigheder, der som denne berørte relationen og distinktionen mellem kristne og muslimer i Egypten i dag, gav anledning til høj latter blandt både muslimer og kristne, men også en befriende følelse af at have et fælles sprog. De få danskere, der sad med omkring bordet, var selv enten oprindelig egypter eller havde stort forkendskab til muslimkristen relationer i Egypten, hvilket var med til at forstærke oplevelsen af, at gruppen omkring bordet var en gruppe af insidere. Dialogen gennem vittighederne handlede om religionsmødet i Egypten og om det, der gjorde ondt $\mathrm{i}$ den forbindelse. Men i modsætning til de indlejrede tabuer i den arrangerede dialog, som ikke gjorde det muligt at berøre visse magtrelationer, så berørte vittighederne disse. De indlejrede tabuer var ikke kun defineret af arrangørernes tabuer knyttet til forsøget på at kontrollere kaosset i det liminale rum, men også af de forskellige samfundsmæssige kontekster. Mens Mohammed-tegningekrisen således delvis syntes at være et tabu for de danske deltagere, så handlede en anden af sessionerne om, hvordan en gruppe af egyptiske muslimske og kristne ledere $\mathrm{i}$ samarbejde havde fors $\emptyset \mathrm{gt}$ at skabe fred og forsoning efter knivoverfald i tre koptiske kirker med efterfølgende sammenstød mellem muslimer og kristne i Aleksandria i påsken samme år. Der var en åbenhed over for at tale om konkrete og voldelige konflikter. Hvad man til gengæld undlod at italesætte, var den grundlæggende ulige magtrelation mellem de to parter. Ved at indskrive dette tabu i jokens form, blev noget væsentligt fortalt, uden at nogen af de tilstedeværende følte sig personligt ramt af forskelssætningen på kristne og muslimer.

I modsætning til den erfaringsbaserede dialog under pilgrimsfærden blev vittighederne samtidig en symbolsk bekræftelse på, at hvad man end foretog sig under dialogmødet, ville deltagerne vende tilbage til en virkelighed, hvor forholdet mellem kristne og 
muslimer var karakteriseret ved ulige magt bundet op i konkrete samfundsformationer. Den befriende følelse hang måske netop sammen med, at præsten gennem fortællingen af vittigheder ikke lagde ansvaret for forandring på den enkelte dialogdeltager, men forbandt ansvaret med samfundets magthierarki og struktur. Den fælles latter blev en kollektiv renselse og erkendelse af, at vi alle efter dialogmødet ville træde ud i et uforandret samfund, uanset hvor meget vi selv havde forandret os. På denne måde blev latteren en anden variant af en menneske-til-menneske-relation. Spørgsmålet er så, om netop det safe space, der indtil da var bygget op, gjorde denne fælles latter mulig.

\section{Konklusion: det transformerede subjekt}

Som deltager i den arrangerede religionsdialog forventes man at træde forandret ud af mødet. I 'Vejledning i religionsmøde' beskrives denne forandring som "et udtryk for udvikling i mødet med det, som er fremmed og nyt, og som en frugt af Helligåndens virke" (Vejledning i religionsmøde 2008). Det understreges samtidig, at nogle muligvis vil skifte religion, men at dette aldrig må ske under tvang, trusler eller med lokkemidler. Målet er dog ikke, som nævnt, at den enkelte deltager træder ud af mødet som konverteret til en anden religion. Hvilken form for transformation er det så egentlig, der lægges op til?

Som udgangspunkt skal de forskelssætninger, som defineres gennem afsættet for dialogen, forsvinde på bestemte måder, mens andre ikke skal. Den position, der står parat til at gribe en, er det at være menneske - først. Det ændrer dog ikke ved, at dialogen også etablerer andre positioner. En er positionen som den professionelle dialogdeltager, der forventes at igangsætte og være ambassadør for lignende dialogformer i egne sammenhænge. En anden er den 'gode' eller 'ægte' kristne, som er parat til at udsætte sig for åbenhedens risiko, og derfor møder 'de andre' med åbenhed og nysgerrighed. Men hvor træder muslimen ud, når dialogen ikke som missionen har konvertering som mål? Måske er det muligt at tale om en position, der med henvisning til kristendommen tilbyder en position som 'kristen' muslim?

I udgangen af religionsdialogens rituelle rum synes dialogen at adskille sig fra det klassiske overgangsritual. Der står ikke nogen tydelig ny social position klar på den anden side. Og slet ikke en position, der nødvendigvis anerkendes $\mathrm{i}$ den politiske og sociale kontekst, som den enkelte vender tilbage til. Det illustreres af denne artikels indledende reference til polemikken om Københavns biskop. Udfordringen er, at man med tilbagevenden til sin oprindelige sammenhæng træder tilbage $\mathrm{i}$ en kontekst, hvor den kollektive forskelstænkning, man i dialogen har forsøgt at overskride, er dominerende. At forbinde erfaringen fra religionsdialogen bliver 
endnu vanskeligere, når man træder ud i en kontekst, der potentielt forties, som det er tilfældet i de to sidste eksempler. Problemet er, at konflikten, der skal forsvinde, befinder sig på en anden skala end religionsdialogens. De arrangerede dialogmøder kan give den enkelte oplevelsen af at se 'den anden' som menneske og dermed selv igennemgå en udvikling, men det transformerer ikke nødvendigvis samfundets kaos til orden. Mens religionsdialogen i sit ideal netop handler om at adskille det politiserede fokus på religion fra den enkeltes tro og Gudsforhold, ja, så adskilles de ikke i den sociale praksis.

\section{Forfatterbiografi}

Lise Paulsen Galal er antropolog, ph.d. i Interkulturelle Studier, og lektor i Kultur- og Sprogmødestudier ved Roskilde Universitet. Hun er projektleder af det kollektive forskningsprojekt 'The Organised Cultural Encounter', der er finansieret af Det Frie Forskningsråd, samt leder af den danske del af projektet 'Defining and Identifying Middle Eastern Christian Communities in Europe', der er finansieret af HERA - Humanities in the European Research. Hun har bla. publiceret om forholdet mellem muslimer og kristne i Egypten, Danmark og Europa.

\section{Referencer}

Abu-Lughod, Lila, 1991: "Writing against culture," in: Fox, R.G. (ed.): Recapturing anthropology: Working in the present, School of American Research Press, Santa Fe.

Ahmed, Sara, 2007: "Multiculturalism and the Promise of Happiness," in: New Formations, Vol. 63, No. 1, pp. 121-137.

Askins, Kye and Pain, Rachel, 2011: "Contact zones: participation, materiality, and the messiness of interaction," in: Environment and Planning D: Society and Space, Vol. 29, pp. 803-821.

Enevoldsen, Simon Muff, 2015: 'Bør biskop repræsentere folkekirken i tværreligiøst forum?" in: Kristeligt Dagblad, 29. juli 2015, http://www.kristeligt-dagblad.dk/kirke-tro/skal-biskop-repraesenterefolkekirken-i-tvaerreligioest-forum (læst 2. november 2015).

Foucault, Michel, 2002: Overvågning og Straf, Det Lille Forlag, Frederiksberg. 
Foucault, Michel, 2003: "The subject and power," in: Rabinow, Paul and Rose, Nikolas (eds.), The Essential Foucault, The New Press, New York.

Galal, Lise Paulsen, 2007: "Hvor sandheden er ilde hørt - hjælper latteren," in: Jordens Folk - Etnografisk Revy, Vol. 42, Nr. 3, s. 36-41.

Hall, Stuart, 1996: "Introduction: Who Needs "Identity?," in: Hall, Stuart \& Du Gay, Paul (eds.): Questions of Cultural Identity, Sage, London.

Hansen, Henrik Lindberg, 2009: Om Dialog. Den Dialogiske Ånd \& Forståelsen af det Anderledes, Unitas Forlag, Frederiksberg.

Hansen, Henrik Lindberg, 2015: Christian-Muslim Relations in Egypt: Politics, Society and Interfaith Encounters, I.B. Tauris, London.

Hjelm, Titus, 2014: "Understanding the New Visibility of Religion. Religion as Problem and Utility," in: Journal of Religion in Europe, 7 (2014), pp. 203-222.

Jørgensen, Theodor, 2000: Mission, dialog og omvendelse - et spфrgsmål om engagement, respekt og tillid. http://www.islamstudie.dk/dialog_dialog.theo.htm (læst 2. november 2015).

Kivisto, Peter, 2014: Religion and Immigration. Migrant Faiths in North America and Western Europe, Polity Press, Cambridge.

Massey, Doreen, 2005: For Space, Sage, London.

Ministry of Foreign Affairs of Denmark, 2015: Evaluation of the Danish Arab Partnership Programme. Synthesis report by Niras and Integrity, Evaluation Department, Ministry of Foreign Affairs of Denmark, Copenhagen.

Müller, Floris, 2012: "Making contact. Generating interethnic contact for multicultural integration and tolerance in Amsterdam," in: Race Ethnicity and Education, Vol. 15, No. 3, pp. 425-440.

Ortner, Sherry B., 2006: Anthropology and social theory: Culture, power, and the acting subject, Duke University Press, Durham, NC.

Rasmussen, Lissi, 1997: Diapraksis og dialog mellem kristne og muslimer, Aarhus University Press, Aarhus. 
Rasmussen, Lissi, 2007: Bridges Instead of Walls. Christian-Muslim Interaction in Denmark, Indonesia and Nigeria, Lutheran University Press, Minneapolis, Minnesota.

Riis, Anita Holm, 2006: Kulturmфdets hermeneutik - en filosofisk analyse af kulturmødets forudsatninger, Univers, Aarhus.

Sjørup, Lene (red.), 2007: Vendepunkter. Religion mellem konflikt og forsoning, Syddansk Universitetsforlag, Odense.

Skov-Jakobsen, Peter, 2015: "Samtalen mellem religioner er vigtig," in: Kristeligt Dagblad, 31. juli 2015, http://www.kristeligtdagblad.dk/kronik/samtalen-mellem-religioner (læst 4. december 2015).

Staunæs, Dorthe, 2003: "Where have all the subjects gone?" in: NORA, vol. 11, nr. 2.

Tranekjær, Louise, 2007: "Kulturmøder til forhandling: Betydningen af 'kultur' i praktiksamtaler med voksne med dansk som andetsprog," in: Tidsskriftet Antropologi, Nr. 56, s. 87-110.

Gennep, Arnold Van, 1960: The Rites of Passage. University of Chicago, Chicago.

Vejledning i religionsmøde, 2008, ved Folkekirke og Religionsmøde. http://www.religionsmoede.dk/index.php/materialer/fr-materialer (læst 27. oktober 2015).

Wilson, Helen F., 2014: "The possibilities of tolerance: intercultural dialogue in a multicultural Europe," in: Environment and Planning D: Society and Space, Vol. 32, pp. 852-868.

Wolf, Alain, 2012: "Intercultural identity and inter-religious dialogue: a holy place to be?" Language and Intercultural Communication, Vol. 12 , No. 1, pp. 37-55. 